J. Perinat. Med.

6 (1978) 213

\title{
Red cell mass and blood volume in low birth weight infants
}

\author{
R. O. Robinson, P. M. Emerson, D. Howes, M. Fujimura, P. Howat, D. M. Salisbury
}

Department of Paediatrics, University of Oxford, Department of Haematology, United Oxford Hospitals

Hypotension $[5,8,13,18,21]$ and poor pulmonary [27], renal [9], gut [10] and limb [15] blood flow are common accompaniments of hyaline membrane disease (HMD). Small blood transfusions given to improve tissue perfusion and oxygenation would appear therefore to be a logical extension to the management of this condition. The clinical effect of this manoeuvre has been evaluated [20]. In addition advantage can be taken of the fact that haemoglobin A of transfused blood can serve as a marker not only for timing of intraventricular haemorrhage [11] but also for the measurement of red cell mass. This paper describes the method of red cell mass estimation together with the results of its application to very low birth weight infants with HMD.

\section{Method}

Fresh blood transfusions were given when indicated by hypotension or metabolic acidosis, or to replace diagnostic blood loss. Blood was drawn from a panel of donors all of whom were screened for blood cornmunicable disease sincluding cy tomegalovirus. The degree by which the proportion of transfused cells in the circulation rises after a transfusion is determined by two quantities. First the transfused red cell mass (which can be measured) and second the circulating red cell mass at the time of transfusion (which can therefore be calculated).

The total red cell mass (RCM) for babies who have been transfused is the sum of the transfused cells

\section{Curriculum vitae}

R. O. ROBINSON was born in 1942 at Bedford. He was graduated as M.B. B.Ch. 1966 in Cambridge and as M.R.C.P. 1969. He gained the B.M.A. essay prize for students 'The role of the doctor in Modern Society: He gained experiences in severalhospitals between 1966 and 1972, was Research Fellow from January 1972 to October 1973 at the Inst. forMedical

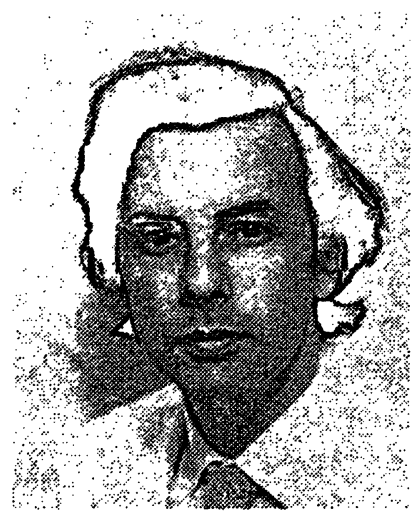

Res. Oxford; Senior Registrar, at the Dept. Paediatrics, Ibadan, Nigeria from November 1973 to November 1974 and Clinical Lecturer in Paediatrics at the University of Oxford, John Radcliffe Hospital. Since November 1976 he is Resident in Neurology (paediatric) at the University of Kentucky, Medical Center, Lexington.

(RCMa) and the mass of the baby's own cells (RCMf).

$$
\mathrm{RCM}=\mathrm{RCMa}+\mathrm{RCMf}
$$

Since the KLEIHAUER technique expressed the number of adult cells compared to the number of fetal cells the relationship before a transfusion may be expressed

$$
\frac{\mathrm{RCMa}}{\mathrm{MCVa}}=\mathrm{a}_{1}\left(\frac{\mathrm{RCMf}}{\mathrm{MCVf}}+\frac{\mathrm{RCMa}}{\mathrm{MCVa}}\right)
$$


Where MCVa and MCVf are the mean cell volume of the adult and fetal red cells respectively and $a_{1}$ is the proportion of adult cells in the circulation before transfusion. After transfusion

$$
\begin{aligned}
& \frac{\mathrm{RCMa}+\mathrm{RCMt}}{\mathrm{MCVa}}=\mathrm{a}_{2}\left(\frac{\mathrm{RCMa}+\mathrm{RCMt}}{\mathrm{MCVa}}\right. \\
& \left.+\frac{\mathrm{RCMf}}{\mathrm{MCVf}}\right)
\end{aligned}
$$

Where RCMt is the red cell mass transfused, and $\mathrm{a}_{2}$ is the proportion of adult cells in the circulation after transfusion. From 1 and 2

$$
\operatorname{RCMf}=\frac{\left(1-a_{1}\right) M C V f}{a_{1} M C V a+\left(1-a_{1}\right) M C V f}
$$

and from 2 and 3

$$
\operatorname{RCMf}=\frac{\left(1-a_{1}\right)}{a_{1}-a_{2}} \cdot \frac{\left(a_{2}-1\right)}{1} \cdot \frac{M C V f}{M C V a} \cdot \operatorname{RCMt}(5)
$$

The expressions on the right hand side of equations 4 and 5 must equal each other (eliminating RCMf) and may be expressed.

$$
R C M=\frac{1-a_{2}}{a_{2}-a_{1}} \cdot \frac{M C V f-(M C V f-M C V a) a_{1}}{M C V a}
$$

. RCMt

Taking figures of 86 cubic $\mu$ (16) and 118 cubic $\mu$ for $\mathrm{MCV}_{\mathrm{a}}(28)$ and $\mathrm{MCVf}$ respectively.

$$
\mathrm{RCM}=\frac{1-\mathrm{a}_{2}}{\mathrm{a}_{2}-\mathrm{a}_{1}} \cdot \frac{118-32 \mathrm{a}_{1}}{86} \cdot \mathrm{RCMt}
$$

By inserting into this expression the values for the proportion of adult cells circulating before and after transfusion together with the red cell mass of the transfused cells, the red cell mass before each transfusion can be derived.

Blood for haematocrit estimation was taken into dry syringes (after withdrawal of $1-2 \mathrm{ml}$ to flush the dead space of the catheter) and transferred to heparinised haematocrit tubes (CAPILETS, Dade) for centrifugation on a HAWKSLEY micro haemato- crit centrifuge for not less than five minutes. No corrections have been made for plasma trapping. Regrettably since samples were initially taken only for estimation of the proportion of transfused cells in order to time IVH [11], the haematocrit of the transfused blood was not obtained in 6 of the 9 babies in whom serial changes of the babies fetal red cells were measured. In these babies we have assumed the donor haematocrit was .40 since the normal range of the haematocrit in healthy young women is $.35-.45$ (and the great majority of our donors were nurses). This assumption increases the maximum error of red cell mass estimation in these babies by only $\pm 5 \%(95 \%$ confidence limits).

At the same time 200-300 micro litres of blood were taken into sequestrene tubes from which thin blood films were prepared and stained within 24 hours by SHEPARDS modification [22] of the KLEIHAUER, BrAUN, and BETKE technique [17]. The proportion of cells contining haemoglobin $F$ were counted by two of us (P.E. and D.H.) who had no knowledge of the timing of transfusions.

The mean initial red cell mass values have been corrected for known diagnostic blood loss prior to transfusion. The variation from the mean of serial measurements of red cell mass was $3.0 \mathrm{ml} / \mathrm{kg}$ in 13 of 19 estimations (68\%) when performed in 9 babies in whom there was no reason to suspect occult haemorrhage. Blood volume was estimated by correction of the calculated red cell mass with the arterial haematocrit. Mean values are expressed as the mean $\pm \mathrm{SD}$. The significance of difference between means was tested by "students" unpaired $\mathrm{t}$ test.

Red cell mass (RCM) and blood volume (BV) measurements were available in 23 babies whose characteristics are shown in the table I. 19 had HMD and 15 of these were ventilated. 14 infants died in whom 10 had intraventricular haemorrhage. This group is not representative of our low birthweight

Tab. I. Characteristics of Babies Studied

\begin{tabular}{lc}
\hline Gestational age (weeks) & $29.2 \pm 2.4$ \\
Birthweight (grams) & $1104 \pm 288$ \\
Sex male: female & $15: 8$ \\
Outcome died: survived & $14: 9$ \\
\hline
\end{tabular}


population; in the first part of this study, although specimens for estimation of the proportion of transfused cells were collected, they were only studied if the baby subsequently died [11].

The umbilical cord was clamped immediately after delivery. No baby was clinically shocked at birth. Umbilical arterial and venous catheters were introduced at birth during the resuscitation procedure for blood sampling and clinical monitoring purposes. Where possible the umbilical venous catheter tip was directed through the ductus venous. The catheter tip positions were checked on X-ray and adjusted so that the umbilical arterial catheter tip lay anterior to the fourth lumbar vertebra and the umbilical venous catheter tip lay just above the diaphragm. Continuous aortic and central venous pressures were measured in 18 and 7 babies respectively using Elcomatic transducers. Heart rate was taken from the arterial pressure pulse or from a Cardiostore (SE Labs). These variables were displayed on a Devices M19 6 channel recorder. The mean and standard deviation of systolic and diastolic arterial and central venous pressures were derived by extracting these values manually from the record at five minute intervals. The mean of the five minute values for the previous hour was used to examine the relationship between RCM or $\mathrm{BV}$ and arterial and central venous pressures.

\section{Results}

The median age of transfusion was 6.0 hours after birth (range 0.5 to 30 hours). The mean initial blood volume was $66.3 \pm 17.9 \mathrm{ml} / \mathrm{kg}$ (range $36-102 \mathrm{ml} / \mathrm{kg}$ ). The mean initial red cell mass was $32.9+9.6 \mathrm{ml} / \mathrm{kg}$ (range $17-59 \mathrm{ml} / \mathrm{kg}$ ). Babies born by caesarean section had a higher RCM $(39 \pm 10.2 \mathrm{ml} / \mathrm{kg})$ than babies born vaginally (30.2 $\pm 8.3 \mathrm{ml} / \mathrm{kg}$ ) - p $<0.05$ (Fig. 1).

The expected correlation between RCM and the PCV at the time of transfusion was confirmed (Fig. 2).

No correlation with RCM or BV was detected in respect of birth weight, gestational age, development or severity of HMD, development of intraventricular haemorrhage or survival, or in respect of arterial pressure or heart rate.

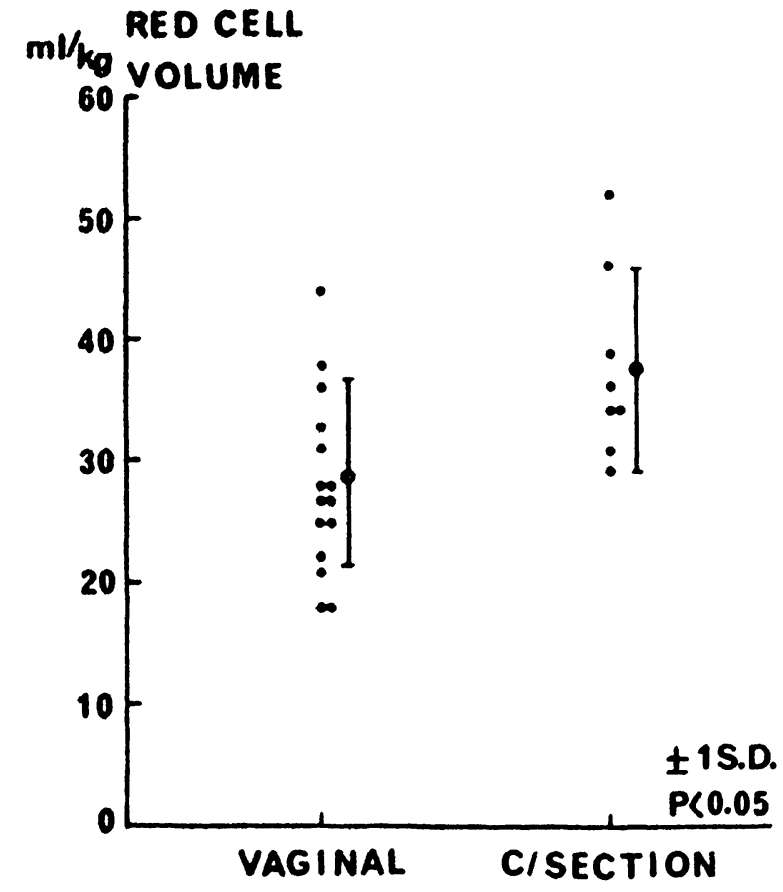

Fig. 1. Red cell mass of low birthweight infants born by Caesarean section and vaginally. Mean $\pm S$. D. is indicated.

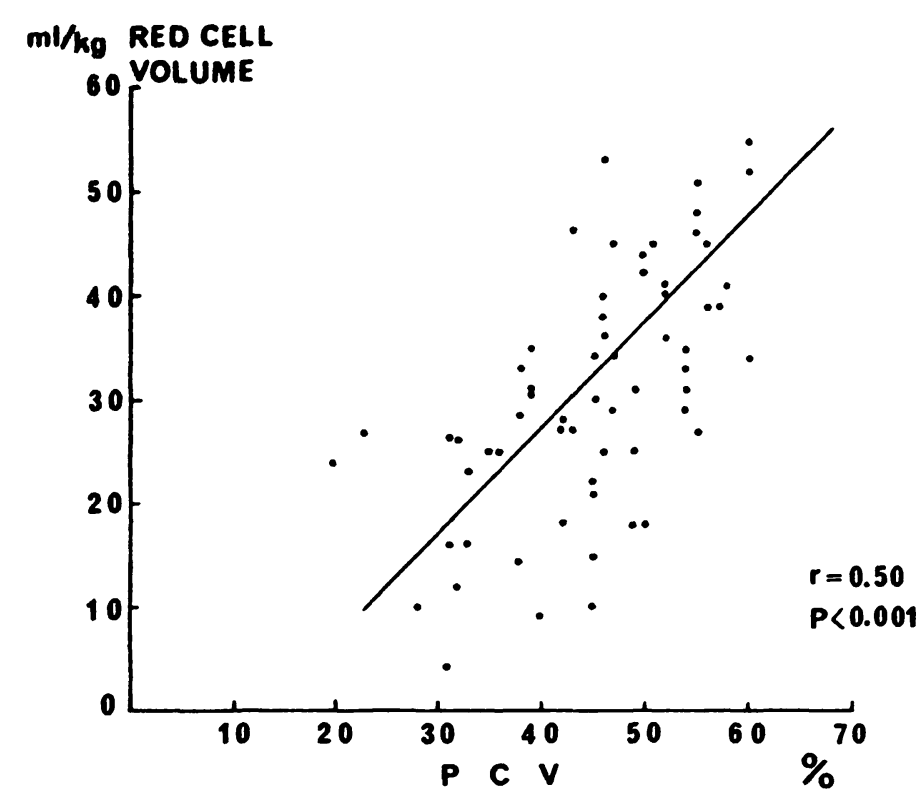

Fig. 2. The relationship between red cell mass and haematocrit in low birthweight infants. $R C M=1.02 \mathrm{PCV}$ $-13.5 . R=0.50 . p<0,001$

\section{Discussion}

As already pointed out the data used in this study was obtained for other purposes. In order to illustrate the method of RCM estimation we have had 
to make two assumptions. First the value for the donor haematocrit (see above) and secondly the mean cell volume for the transfused cells and for the babies cells. From the function in equation 6 it will be seen that the major determinants of RCM are $a_{1}$ and $a_{2}$. Should the actual mean cell volume differ from the assumed mean cell volume by as much $5 \mathrm{cu} \mu$, this will alter the value of RCM by only $4 \%$. Since the effect of a placental transfusion increases the red cell mass by a mean value of $61 \%$ [25] the true variability of the method (see above) which includes the theoretical inaccuracies introduced by the assumptions, is much less than the variability introduced by external factors.

The major determinant of the infants RCM is the time allowed to elapse between delivery and cord clamping. The majority of the babies were apnoeic at birth and the cord was clamped immediately ( $<15$ seconds) in order to allow resuscitative measures to be taken without delay. USHER et al. [25] studied 9 full term infants whose cords were clamped immediately and YAO et al. [29] studied 83 low birth weight infants whose cords were clamped $<15$ seconds after delivery. Their estimations of the mean red cell mass obtained by correcting the plasma volume by the estimated whole body haematocrit were $32 \mathrm{ml} / \mathrm{kg}$ and $31 \mathrm{ml} /$ $\mathrm{kg}$ respectively and are in good agreement with our results.

The variation in RCM between babies has also been found by other workers. BRATTEBY [3] for example measured $\mathrm{RCM}$ directly by $\mathrm{Cr}_{51}$ tagging of red cells in babies whose cords had been clamped after umbilical arterial pulsations had ceased. He found a range of $27.4 \mathrm{ml} / \mathrm{kg}$ to $53.1 \mathrm{ml} / \mathrm{kg}$ in 5 babies of comparable gestational age to ours and commented that the variability increased with decreasing gestational age. Since the placenta constitutes a greater proportion of the fetoplacental mass in the pre-term as opposed to the term infant, small variations in obste tric technique at delivery which affect the volume of the placental transfusion may have a proportionately greater effect in the pre-term infant.

BRATTEBY [3] also demonstrated a relationship between the RCM and haematocrit. Since our function for estimating RCM does not include the haematocrit, the correlation between $\mathrm{RCM}$ and haematocrit from our data which agrees very closely with Bratteby's, offers an independent validation of our results.

Similarly the association between the high RCM and Caesarean section was confirmed by the association between a higher haematocrit and Caesarean section. The RCM of babies delivered by Caesarean section at term is lower than that of babies delivered vaginally because the former do not receive a placental transfusion [29]. Our data shows the opposite effect. However the babies delivered vaginally were more hypoxic and acidotic than babies delivered by Caesarean section, (all but 1 of the Caesarean sections were elective and for maternal indications). Consequently their cords were clamped immediately on delivery in order to expedite resuscitation. Hypoxia and acidosis redistributes the fetal circulation preferentially to the brain, adrenals, heart and placenta [6]. In the pre-term infant the placenta constitutes a larger proportion of the feto-placental mass than at term. This coupled with the possibility that during birth itself blood may pass from the baby to the placenta suggests that if the cord is clamped immediately the pre-term baby born vaginally is deprived of a greater contribution from the placenta than the babies born by Caesarean section.

That $\mathrm{RCM} / \mathrm{kg}$ or blood volume $/ \mathrm{kg}$ is independent of the birthweight and gestational age is in general agreement with the findings of others $[2,7,24,30]$, as is the findings that arterial pressure is maintained independently within wide limits of the RCM or blood volume $[1,4]$.

Our data do not support the suggestion that variations in RCM influence the incidence or severity of hyaline membrane disease. An alternative explanation for the low RCM found by others $[4,7,12,14,25]$ may be that hypoxia and acidosis predispose to a low RCM (for the reasons given above) and also to hyaline membrane disease, (by inhibition of surfactant synthesis). It is possible therefore that the association is not causative but is due to the fact that it is particularly those babies most likely to get hyaline membrane disease that are denied a placental transfusion. 


\section{Summary}

Small serial blood transfusions may be used in hyaline membrane disease to augment tissue perfusion and oxygenation. This paper describes a method of calculating the red cell mass (RCM) at each transfusion by observing the change in the proportion of adult red cells circulating produced by transfusion of a known mass of adult red cells. The mean RCM of 23 low birthweight infants was $32.9 \pm 9.6 \mathrm{ml} / \mathrm{kg}$. There was no correlation between RCM - or blood volume - and development or severity of hyaline membrane disease, or in respect of arterial pressure or heart rate. The mean RCM of babies born by Caesarean section was $39 \pm 10.2 \mathrm{ml} / \mathrm{kg}$ whereas babies born vaginally had a mean RCM of $30.2 \pm 8.3 \mathrm{ml} / \mathrm{kg}-\mathrm{p}<0.05$. We conclude that low birthweight babies have a wide range of red cell mass and blood volume, and if the cord is clamped immediately after vaginal delivery the pre-term infant is deprived of a greater contribution from the placenta than the pre-term infant born by Caesarean section. It has been suggested that a low RCM may predispose to HMD. However the umbilical cord of babies born with birth asphyxia is more likely to be clamped immediately on delivery in order to expedite resuscitation. The association between hyaline membrane disease and birth asphyxia is well recognised. In this study immediate cord clamping was practiced on all infants irrespective of the need for resuscitation. We suggest therefore that the association found by others therefore is not causative but is due to the fact that it is those babies most likely to get hyaline membrane disease who are denied a placental transfusion.

Keywords: Blood volume, caesarean section, infant newborn, infant premature.

\section{Zusammenfassung}

Rote-Zell-Masse und Blutvolumen bei Kindern mit niedrigem Geburtsgewicht

Kleine wiederholte Bluttransfusionen werden beim hyalinen-Membran-Syndrom (HMD) angewandt, um die Gewebeperfusion und die Sauerstoffversorgung zu vermehren. Diese Arbeit beschreibt eine Methode der Berechnung der Roten-Zell-Masse (RCM) nach jeder Transfusion durch Beobachtung der Veränderung in dem Anteil von reifen zirkulierenden roten Zellen, die durch die Transfusion einer bekannten Masse von reifen roten Zellen hervorgerufen wird. Die durchschnittliche RCM bei 23 Kindern mit niedrigem Geburtsgewicht war 32,9 $\pm 9,6$ kg. Da gab es keine Beziehung zwischen RCM-oder BlutVolumen und Entwicklung oder Schwere des HMD, oder in bezug auf arteriellen Druck oder Herzfrequenz. Die durchschnittliche RCM bei Neugeborenen, die durch Kaiserschnitt geboren wurden, war $39 \pm 10,2 \mathrm{ml} / \mathrm{kg}$, während vaginal geborene Kinder eine durchschnittliche $R C M$ von $30,2 \pm 8,3 \mathrm{ml} / \mathrm{kg}(\mathrm{p}<0,05)$ hatten. Wir schließen daraus, daß Kinder mit niedrigem Geburtsgewicht einen weiten Bereich von RCM und Blut-Volumen aufweisen. Außerdem sehen wir, wenn die Nabelschnur unmittelbar nach der vaginalen Entbindung abgeklemmt wird, daß diesen Frühgeborenen ein größerer Beitrag aus der Plazenta als den Frühgeborenen durch Kaiserschnitt vorenthalten wird. Es ist vermutet worden, daß eine niedrige RCM förderlich für ein HMD sein kann. Allerd ings ist es notwendig, die Nabelschnur von asphyktischen Neugeborenen schnell abzunabeln, um eine Wiederbelebung beschleunigt durchführen zu können. Die Verbindung zwischen HMD und Geburtsasphyxie ist gut bekannt. In dieser Studie wurde die Frühabnabelung bei allen Kindern vorgenommen ohne Rücksicht auf die Notwendigkeit der Wiederbelebung. Wir nehmen daher an, daß der Zusammenhang, den andere Autoren gefunden haben, nicht begriindet ist. In der Tat entwickeln solche Neugeborenen wahrscheinlich einen HMD, die keine plazentare Transfusion erhielten.

Schlüsselwörter: Blut-Volumen, Frühgeborene, Kaiserschnitt, Neugeborene.

\section{Résumé}

Masse ery throcytaire et volume sanguin des nouveaux-nés au poids insuffisant

Des petites séries de transfusions sanguines peuvent être utilisées dans la maladie membrane hyaline pour augmenter la perfusion et l'oxygénation des tissus. Cet article décrit une méthode de calcul de la masse érythrocytaire (ME: red cell mass (RCM)) à chaque transfusion par l'observation des changements proportionnels de la circulation des globules rouges adultes produits par transfusion d'une masse connue de globules rouges adultes. La ME moyenne de 23 nouveaux-nés au poids insuffisant s'est située à $32,9 \pm 9,6 \mathrm{ml} / \mathrm{kg}$. Nous n'avons relevé aucune corrélation entre la $\mathrm{ME}$ - ou volume sanguin - et le développement ou la gravité de la maladie membraneuse hyaline, ou la pression artérielle ou la fréquence cardiaque. La ME moyenne des bébés nés par césarienne a été de $39 \pm 10,2$ $\mathrm{ml} / \mathrm{kg}$ tandis que les bébés nés par le vagin ont eu une $\mathrm{ME}$ moyenne de $30,2 \pm 8,3 \mathrm{ml} / \mathrm{Kg}-\mathrm{p}<0,05$. Nous en concluons que les bébés de poids insuffisant possèdent une masse éry throcy taire et un volume sanguin élargis, et si on place un clamp sur le cordon aussitôt après l'accouchement vaginal, le bébé prématuré est privé d'une plus grande contribution du placenta que le bébé prématuré né par césarienne. On a émis la suggestion qu'une ME basse peut prédisposer à la maladie membraneuse hyaline. Néanmoins, il reste sans doute plus recommandable de placer un clamp sur le cordon ombilical des bébés nés avec asphyxie natale aussitôt à l'accouchement pour accélérer la réanimation. On connaît déjá l'association qui existe entre la maladie membraneuse hy aline et l.asphyxie natale. Dans notre étude, nous avons pratiqué la forcipressure immédiate sur tous les enfants, indépendamment de la 
nécessité de réanimation. Nous pensons donc que la corrélation trouvée par d'autres auteurs n'est pas causale, mais dûe au fait que ce sont les bébés qui n'ont pas reçu de transfusion placentaire qui sont le plus prédisposés à avoir une membrane hyaline.

Mots-clés: Césarienne, nouveau-né, prématuré, volume sanguin.

Acknowledgements: PH was in receipt of a grant from the MEDICAL RESEARCH COUNCIL [G974/185C] and DMS was supported by the Sir WILLIAM COXEN MEMORIAL FUND. MF was a BRITISH COUNCIL SCHOLAR. Babies were under the care of Doctors BAUM, BOWER, ELLIS, MONCRIEFF, PICKERING and Professor TIZARD. We thank Miss TOWNSHEND and her nursing colleagues for their help and co-operation. We would also like to thank Professor TIZARD for his help and support.

Bibliography

[1] BARR, P. A., P. E. BAIley, J. E. SUMMERS, G. CASSADY: Lack of relation between arterial blood pressure and blood volume in the pre-term infant. Ped. Res. 10 (1976) 421

[2] BRANS, Y. W., R. R. MILSTEAD, P. E. BAILEY, G. CASSADY: Blood volume estimates in Combs Test positive infants. New Engl. J. of Med. 290 (1976) 1450

[3] BRATTEBY, L. E.: Studies of erythrokinetics in infancy $X$ Red Cell volume of newborn infants in relation to gestational age. Acta Paed. Scand. 57 (1968) 132

[4] BROWN, E. G., R. W. KROUSKOP, F. E. MCDONNELL, A. Y. SWEET: Blood volume and blood pressure in infants with respiratory distress. J. Pediat. 87 (1975) 1133

[5] BUCCI, G., A. SCALAM ANDRE,P.G.SAVIGNONI, M. MENDICINI, S. PICECE-BUCCI, L. PICCINATO: The systemic blood pressure of newborns of low birth weight. A Multiple regression analysis. Acta Paed. Scand. 229 (1972) Suppl. 1

[6] CAM PBELL, A. G. M., G. S. DAWES, A.P.FISHMAN, A. I. HYMAN: Regional redistribution of blood flow in the mature fetal lamb. Circ. Res. 21 (1967) 229

[7] CASSADY, G.: Plasma volume studies in low birth weight infants. Pediatrics 38 (1966) 1020

[8] CHU, J., J. A. ClementS, E. K. COTtoN, M. H. KLAUS, A. Y. SWEET, W. H. TOOLEY: Neonatal Pulmonary Ischeaemia. Pediatrics 40 (1967) Suppl. 709

[9] COURT, R. C.: Renal function in the respiratory distress syndrome. Acta Paed. Scand. 51 (1962) 313

[10] DUNN, P. M.: Intestinal obstruction in the newborn with special reference to transient functional ileus associated with respiratory distress syndrome. Arch. Dis. Child. 38 (1963) 459

[11] EMERSON, P., M. FUJIMURA, P. HOWAT, D. HOWES, J. KEELING, R. O. ROBINSON, D. M. SALISBURY, J. P. M. TIZARD: Methods of timing intraventricular haemorrhage. Arch. Dis. Child. 52 (1977) 83

[12] FAXELIUS, G., J. R. RAYE, R. L. GUTBERLET, S. WWANSTRÖM, N. DYER, A. BRILL, M. T. STAHLMAN: Comparison of red cell volume in infant with hyaline membrane disease and infants with other forms of respiratory distress. Quoted by BROWN, E. G., R. W. KROUSKOP. F. E. MCDONNELL, A. Y. SWEET. J. Pediat. 87 (1970) 1133
[13] GUPTA, J. M., J. W. SCOPES: Observations on blood pressure in newborn infants. Arch. Dis. Child. 40 (1965) 637

[14] INALL, J. A., M. M. BLUHM, M. M. KERR, T. A. DOUGLAS, C. S. HOPE, J. H. HUTCHINSON: Blood volume and haematocrit studies in respiratory distress syndrome of the newborn. Arch. Dis. Child. 40 (1965) 480

[15] KIDD, L., H. LEVISON, P. GEMMEL, A. AHARON, P. R. SWYER: Limb blood flow in the normal and sick newborn. Amer. J. Dis. Child. 112 (1966) 402

[16] KLAUSS, M. H., A. A. FANAROFF: Care of the high risk infant. Saunders, W.B.,Philadelphia, London, Toronto, 1973

[17] KLEIHAUER, E., H.. BRAUN, K. BETKE: Demonstration on fetalen Hamoglobin in den Erythrocyten ines Blutansstricks. Klin. Wschr. 35 (1957) 637

[18] HAgASHIMO, S. M., F. H. ADAMS: Postnatal circulatory and metabolic adjustments in normal and distressed premature infants. Biol. Neonat. 8 (1965) 177

[19] NELIGAN, G. A., C. A. SMITH: The blood pressure of newborn infants in asphyxial states and hyaline membrane disease. Pediatrics 26 (1960) 735

[20] RoBINSON, R. O., M. FUJIMURA, P. HOWAT, D. M. SALISBURY. The effect of blood transfusion in low birthweight infants. Arch. Dis. Child. 52 (1977) 696

[21] RUdolPh, A. M., J. E. DRORBAUGH, P. A. M. AULD, A. J. RUDOLPH, A. S. NADUS, C. A. SMITH, J. P. HUBELL: Studies on the circulation in the neonatal period. The circulation in the respiratory distress syndrome. Pediatrics 27 (1961) 551

[22] SHEPARD, M. K., D. J. WEATHERALL, C. L. CONLEY: Semi quantitative estimation of the distribution of fetal haemoglobin in red cell populations. Bull. Johns Hopkins Hosp. 110 (1962) 293

[23] USHER, R., J. LIND: Blood volume of the newborn premature infant. Acta Paed. Scand. 54 (1963) 419

[24] USHER, R., M. SHEPHARD, J. LIND: The blood volume of the newborn infant and placental transfusion. Acta. Paed. Scand. 52 (1963) 497

[25] USHER, R. H., S. SAIGAL, A. O'NEILL, Y. SURAINDER, L.-B. CHUA: Estimation of red blood cell volume in premature infants with and whithout respiratory distress syndrome. Biol. Neonate 26 (1975) 241 
[26] WALlgREN, G., J. S. HaNSEN, B. S. TABAKIN, N. RAIHA, E. VAPAAVUORI: Quantitative studies of the human neonatal circulation V. Haemodynamic findings in premature infants with and without respiratory distress. Acta: Paed. Scand. 179 (1967) Suppl. 1.

[27] WINTROBE, M. M.: Clinical Haematology. 6th edition Lee and Ferbeger, Philadelphia, 1967
[28] YAO, A. C., A. WIST, J. LIND: The blood volume of the newborn infant delivered by caesarean section. Acta. Paed. Scand. 56 (1967) 585

[29] YAO, A. C., J. LIND, R. TIISALA, K. MICHELSSON: Placental transfusion in the premature infant with observations on a clinical course and outcome. Acta. Paed. Scand. 58 (1969) 561

Received April 11, 1977. Accepted February 26, 1978.

Dr. R. O. Robinson Dept. of Neurology

Albert B. Chandler Med. Ctr. University of Kentucky Lexington, Kentucky 40506 U S A 